\title{
The influence of iron and light on net community production in the Subantarctic and Polar Frontal Zones
}

\author{
N. Cassar ${ }^{1, *}$, P. J. DiFiore ${ }^{1}$, B. A. Barnett ${ }^{1}$, M. L. Bender ${ }^{1}$, A. R. Bowie ${ }^{2}$, B. Tilbrook ${ }^{2,3}$, K. Petrou ${ }^{4}$, K. J. Westwood ${ }^{5}$, \\ S. W. Wright ${ }^{5}$, and D. Lefevre ${ }^{6}$ \\ ${ }^{1}$ Department of Geosciences, Princeton University, Princeton, NJ 08544, USA \\ ${ }^{2}$ Antarctic Climate and Ecosystems CRC, University of Tasmania, Private Bag 80, Hobart, Tasmania 7001, Australia \\ ${ }^{3}$ Commonwealth Scientific and Industrial Research Organisation (CSIRO), Marine and Atmospheric Research, Hobart, \\ Tasmania 7001, Australia \\ ${ }^{4}$ Plant Functional Biology and Climate Change Cluster (C3), University of Technology, Sydney, P.O. Box 123, \\ Broadway NSW 2007, Australia \\ ${ }^{5}$ Australian Antarctic Division and Antarctic Climate and Ecosystem Cooperative Research Center, Kingston, \\ Tasmania 7050, Australia \\ ${ }^{6}$ Université de la Méditerranée, Laboratoire de Microbiologie Géochimie et Ecologie Marines (LMGEM) CNRS/INSU, \\ UMR 6117, Centre d'Océanologie de Marseille, Campus de Luminy, Case 901, 13288 Marseille Cedex 9, France \\ *now at: Division of Earth and Ocean Sciences, Nicholas School of the Environment, Duke University, \\ Durham, NC 27708, USA
}

Received: 16 June 2010 - Published in Biogeosciences Discuss.: 21 July 2010

Revised: 20 December 2010 - Accepted: 4 January 2011 - Published: 1 February 2011

\begin{abstract}
The roles of iron and light in controlling biomass and primary productivity are clearly established in the Southern Ocean. However, their influence on net community production (NCP) and carbon export remains to be quantified. To improve our understanding of NCP and carbon export production in the Subantarctic Zone (SAZ) and the northern reaches of the Polar Frontal Zone (PFZ), we conducted continuous onboard determinations of NCP as part of the Sub-Antarctic Sensitivity to Environmental Change (SAZSense) study, which occurred in January-February 2007. Biological $\mathrm{O}_{2}$ supersaturation was derived from measuring $\mathrm{O}_{2} / \mathrm{Ar}$ ratios by equilibrator inlet mass spectrometry. Based on these continuous measurements, NCP during the austral summer 2007 in the Australian SAZ was approximately $43 \mathrm{mmol} \mathrm{O}_{2} \mathrm{~m}^{-2} \mathrm{~d}^{-1}$. NCP showed significant spatial variability, with larger values near the Subtropical front, and a general southward decrease. For shallower mixed layers $(<50 \mathrm{~m})$, dissolved $\mathrm{Fe}$ concentrations and $\mathrm{Fe}$ sufficiency, estimated from variable fluorescence, correlated strongly with NCP. The strong correlation between NCP and dissolved Fe
\end{abstract}

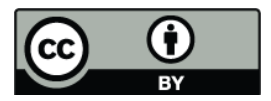

Correspondence to: N. Cassar (nicolas.cassar@duke.edu) may be difficult to interpret because of the correlation of dissolved Fe to MLD and because the concentration of iron may not be a good indicator of its availability. At stations with deeper mixed layers, $\mathrm{NCP}$ was consistently low, regardless of iron sufficiency, consistent with light availability also being an important control of NCP. Our new observations provide independent evidence for the critical roles of iron and light in mediating carbon export from the Southern Ocean mixed layer.

\section{Introduction}

The Subantarctic Zone (SAZ) and Polar Frontal Zone (PFZ) represent important high-nutrient low chlorophyll (HNLC) regions of the world's oceans. Over glacial-interglacial timescales, changes in the degree of stratification and availability of iron and light putatively shaped productivity in these regions (Mitchell et al., 1991; Sigman and Boyle, 2000; Martinez-Garcia et al., 2009). Conversely, regional productivity may not only substantially effect Southern Ocean biogeochemistry, but also productivity of extrapolar oceans as well as $\mathrm{CO}_{2}$ and global climate (Sigman and Boyle, 2000). Variations in differential drawdown of silicic acid and nitrate

Published by Copernicus Publications on behalf of the European Geosciences Union. 
in subantarctic waters influences the nutrient content of subantarctic mode water, which is believed to be a dominant source of nutrients to ocean ecosystems at low latitudes (Sarmiento et al., 2004). In order to improve our understanding of productivity and carbon biogeochemistry in the SAZ and PFZ, the SAZ-Sense (Sub-Antarctic Sensitivity to Environmental Change) study was conducted in January and February 2007 onboard the Australian icebreaker RSV Aurora Australis.

As part of this collaborative project, we present high resolution net community productivity (NCP) estimates based on continuous shipboard dissolved $\mathrm{O}_{2} / \mathrm{Ar}$ measurements (Cassar et al., 2009). NCP corresponds to gross primary productivity (GPP) minus community respiration (i.e. the sum of auto- and hetero-trophic respiration) within the surface ocean. At steady-state or over large spatial and temporal scales, NCP is equivalent to new production, and because little particulate organic carbon is stored in the euphotic zone, $\mathrm{NCP}$ approximates organic carbon export from the surface ocean (Falkowski et al., 2003). We examine the environmental factors regulating NCP in the SAZ and PFZ. Incubation and fertilization experiments have clearly demonstrated that iron plays a key role in limiting phytoplankton growth in high HNLC regions of the Southern Ocean (de Baar et al., 2005; Martin, 1990), with light modulating the response to iron supply (de Baar et al., 2005; Boyd et al., 1999, 2001; Mitchell et al., 1991). However, determination of the dependence of NCP on iron and light has proven to be more difficult, partly because of the heretofore limited NCP observations. In this paper, we interrogate high resolution NCP measurements in the context of ancillary biogeochemical properties to advance our understanding of the roles of light and iron in regulating Southern Ocean productivity.

\section{Materials and methods}

\subsection{NCP from oxygen mass balance}

Due to the central role that oxygen plays in biological redox reactions, the biological oxygen budget first and foremost reflects the net energetic balance of the surface ocean. It also mirrors net organic carbon production due to the stoichiometric coupling of oxygen and carbon. Oxygen concentrations in the mixed layer are also influenced by physical processes such as bubble injection, and temperature and pressure changes. Given that $\mathrm{Ar}$ has solubility properties similar to those of oxygen (Craig and Hayward, 1987), $\mathrm{O}_{2}$ supersaturation derived from physical processes can be estimated from Ar supersaturation ([Ar $\left.]_{\mathrm{sat}}\right)$. The net oxygen supersaturation derived from biology $\left(\left[\mathrm{O}_{2}\right]_{\text {biol }}\right)$ is equal to the total oxygen concentration minus the oxygen derived from physical processes $\left(\left[\mathrm{O}_{2}\right]_{\text {phys }}\right) . \mathrm{O}_{2}$ concentrations in excess or deficit of saturation after removing the effects of physical processes indicate either net autotrophy or net heterotrophy within the mixed layer, respectively (Spitzer and Jenkins, 1989; Emerson, 1987; Emerson et al., 1993):

$$
\begin{aligned}
{\left[\mathrm{O}_{2}\right]_{\text {biol }} } & =\left[\mathrm{O}_{2}\right]-\left[\mathrm{O}_{2}\right]_{\text {phys }} \approx\left[\mathrm{O}_{2}\right]-\frac{[\mathrm{Ar}]}{[\mathrm{Ar}]_{\mathrm{sat}}}\left[\mathrm{O}_{2}\right]_{\mathrm{sat}} \\
& =\frac{[\mathrm{Ar}]}{[\mathrm{Ar}]_{\mathrm{sat}}}\left[\mathrm{O}_{2}\right]_{\mathrm{sat}} \Delta\left(\mathrm{O}_{2} / \mathrm{Ar}\right)
\end{aligned}
$$

where

$\Delta\left(\mathrm{O}_{2} / \mathrm{Ar}\right)=\left[\frac{\left(\left[\mathrm{O}_{2}\right] /[\mathrm{Ar}]\right)}{\left(\left[\mathrm{O}_{2}\right] /[\mathrm{Ar}]\right)_{\mathrm{sat}}}-1\right]$

$\Delta\left(\mathrm{O}_{2} / \mathrm{Ar}\right)$ is defined as the biological oxygen supersaturation.

Neglecting vertical mixing, the net biological oxygen flux is a function of the mass balance between net community oxygen production (hereafter NCP is in terms of oxygen) and exchange of biological oxygen with the atmosphere,

$\operatorname{MLD} \frac{d\left[\mathrm{O}_{2}\right]_{\text {biol }}}{d t}=\mathrm{NCP}-k_{\mathrm{O}_{2}}\left[\mathrm{O}_{2}\right]_{\text {biol }}$

where MLD is the mixed-layer depth, and $k_{\mathrm{O}_{2}}$ is the gas exchange velocity for oxygen (aka piston velocity). Substituting $\left[\mathrm{O}_{2}\right]_{\text {biol }}$ in Eq. (3) with the term on the right-hand side of the equality sign in Eq. (1), $\mathrm{NCP}$ (in $\mathrm{mmol} \mathrm{O}_{2} \mathrm{~m}^{-2} \mathrm{~d}^{-1}$ ) under steady-state conditions can be approximated by

$$
\begin{aligned}
\mathrm{NCP} & \approx k_{\mathrm{O}_{2}}\left[\mathrm{O}_{2}\right]_{\mathrm{sat}} \Delta\left(\mathrm{O}_{2} / \mathrm{Ar}\right) \frac{[\mathrm{Ar}]}{[\mathrm{Ar}]_{\mathrm{sat}}} \\
& \approx k_{\mathrm{O}_{2}}\left[\mathrm{O}_{2}\right]_{\mathrm{sat}} \Delta\left(\mathrm{O}_{2} / \mathrm{Ar}\right)
\end{aligned}
$$

We assume that $\frac{[\mathrm{Ar}]}{[\mathrm{Ar}]_{\mathrm{sat}}}$ in Eq. (4) equals one. In fact, [Ar] typically departs from the saturation concentration by approximately $1 \%$, introducing an error of this magnitude into our NCP estimates. Under net autotrophic conditions in the mixed layer, there is a net oxygen flux out of the ocean. In our discussion, we use NCP and carbon export production interchangeably based on the steady-state assumption inherent in our approach. Under circumstances where the assumption of steady-state is violated and where dissolved organic carbon (DOC) accumulation is a significant fraction of NCP, carbon export production may differ from NCP.

\section{$2.2 \mathrm{O}_{2} / \mathrm{Ar}$ measurements}

Based on Eq. (4), NCP can be derived from (1) the oxygen concentration at saturation $\left(\left[\mathrm{O}_{2}\right]_{\mathrm{sat}}\right),(2)$ a gas exchange rate $\left(k_{\mathrm{O}_{2}}\right)$, and (3) the biological oxygen supersaturation $\left(\Delta\left(\mathrm{O}_{2} / \mathrm{Ar}\right)\right)$. We calculate oxygen solubility from atmospheric pressure, temperature, and salinity measurements (Garcia and Gordon, 1992). The piston velocity for oxygen is estimated from the NCEP/NCAR windspeed reanalysis data product (Kalnay et al., 1996) and the parameterization of Wanninkhof (Wanninkhof, 1992). Piston velocity is weighted for windspeed history at the collection site (Reuer et al., 2007). Finally, biological oxygen supersaturation is 
measured continuously by Equilibrator Inlet Mass Spectrometry (EIMS), a method previously described (Cassar et al., 2009). Briefly, seawater from the ships underway system is pumped through a gas equilibrator, the headspace of which is connected to a quadrupole mass spectrometer for continuous elemental $\mathrm{O}_{2} / \mathrm{Ar}$ ratio measurements. The ion current ratio is calibrated with discrete samples collected every $6 \mathrm{~h}$ and measured on an isotope ratio mass spectrometer (Reuer et al., 2007). From the $\mathrm{O}_{2} / \mathrm{Ar}$ supersaturation, the piston velocity, and the oxygen concentration at saturation, the net biological oxygen flux across the ocean surface is estimated based on Eq. (4). Our measurements of NCP are presented in context of other measurements performed on the SAZ-Sense cruise.

\subsection{Ancillary measurements}

${ }^{14} \mathrm{C}$ gross primary productivity measurements were conducted based on the small bottle technique of Lewis and Smith (1983). See Westwood et al. (2011) for a more detailed description of the GPP measurements performed during SAZ Sense. Six depths were sampled per CTD station ranging from the surface to $125 \mathrm{~m}$. Sub-samples for each depth were then incubated with $\mathrm{NaH}^{14} \mathrm{CO}_{3}$ for $1 \mathrm{~h}$ at 21 light intensities ranging from 0 to $416 \mu \mathrm{mol} \mathrm{m}^{-2} \mathrm{~s}^{-1}$ (CT Blue filter centered on $435 \mathrm{~nm}$ ) in a temperature-controlled unit. ${ }^{14} \mathrm{C}$ production was calculated after accounting for in situ chlorophyll- $a$ (de Salas et al., 2011) and dissolved inorganic carbon concentrations (Johnson et al., 1998). Photosynthesis was plotted vs. irradiance for each depth. The data were fitted with a curve using the equation of Platt et al. (1980). Primary productivity was calculated from photosynthetic parameters $\left(P_{\max }\right.$ and $\alpha$ ), chlorophyll- $a$ depth profiles converted from CTD fluorometry data, $10 \mathrm{~min}$-averaged PAR, and vertical light attenuation. Values were integrated over the total illuminated water-column $(0-150 \mathrm{~m})$, as well as within the mixed layer $\left(0-Z_{\mathrm{m}}\right)$.

NCP was also estimated from changes in the dissolved oxygen $\left(\mathrm{O}_{2}\right)$ concentration over 24-h incubations carried out in on-deck incubations (Gaarder and Gran, 1927). Rates were measured at $1 \%, 3 \%, 10 \%, 20 \%, 40 \%$, and $70 \%$ of surface photosynthetically active radiation (PAR) levels at mixed layer temperature. Dissolved $\mathrm{O}_{2}$ concentration changes were measured using an automated high-precision Winkler titration system coupled to a photometric end-point detector (Williams and Jenkinson, 1982). The overall coefficient of variation for $\mathrm{O}_{2}$ titrations was $0.06 \%$ (Lefevre et al., 2008). Underway $\mathrm{O}_{2}$ measurements were performed with an Aanderaa optode (see Reuer et al., 2007, for method description).

Chlorophyll- $a$ variable fluorescence measurements were made using a Water-PAM (Pulse Amplitude Modulated) fluorometer (Walz, GmbH, Effeltrich, Germany). Surface seawater samples $(3 \mathrm{ml})$ were measured in a quartz cuvette and dark-adapted for $5 \mathrm{~min}$ before measuring maximum quantum yield of PSII $\left(F_{\mathrm{V}} / F_{\mathrm{M}}\right)$ (Measuring light frequency $=6$;
Gain $=22-26$ (depending on algal density); Damping $=1$; Saturating pulse intensity $=>3000 \mu \mathrm{mol}$ photons $\mathrm{m}^{-2} \mathrm{~s}^{-1}$; Saturating pulse width $=0.6 \mathrm{~s}$ ). Maximum quantum yield of PSII $\left(F_{\mathrm{V}} / F_{\mathrm{M}}\right)$ was calculated as the difference between the minimum $\left(F_{\mathrm{O}}\right)$ and maximum $\left(F_{\mathrm{M}}\right)$ fluorescence values $\left(=F_{\mathrm{V}}\right)$ divided by $F_{\mathrm{M}}$ (Schreiber, 2004; Kolber and Falkowski, 1992).

Sampling and analytical procedures for dissolved $\mathrm{Fe}$ and particulate $\mathrm{Fe}$ measurements (inventories and fluxes) followed recommended GEOTRACES protocols outlined for the International Polar Year where possible (Bowie and Lohan, 2009; Bowie et al., 2009). Atmospheric Fe deposition was estimated following a method recently described (Wagener et al., 2008). See Bowie et al. (2009) for a description of the dissolved Fe budget, including the atmospheric Fe deposition measurements, during the SAZ Sense cruise.

\section{Results}

\subsection{Description of the region under study}

The SAZ-Sense study targeted a diamond-shaped grid in the Australian sector of the Southern Ocean south of Tasmania (Trull et al., 2001; Bowie et al., 2011; Herraiz-Borreguero and Rintoul, 2011) (Fig. 1). It encompasses several circumpolar fronts with waters ranging from subtropical through subantarctic to polar. The SAZ region southeast of Australia is strongly influenced by mixing with subtropical water from the north and the extension of the East Australian Current. Deeper waters include Sub-Antarctic Mode Water, Antarctic Intermediate Water, and Upper Circumpolar Deep Water (Sokolov and Rintoul, 2003). Silicate, nitrate and phosphate concentrations increased with latitude and with depth from the Sub-tropical Zone to the Polar Frontal Zone. Nitrate and phosphate concentrations were non-limiting to productivity within the whole of the survey area (Bowie et al., 2011). However, silicate was highly limiting $(<5 \mu \mathrm{M})$ (Franck et al., 2000; Nelson and Treguer, 1992) within the mixed layer with average concentrations of $0.17 \pm 0.06$, $0.55 \pm 0.07$, and $0.65 \pm 0.07 \mu \mathrm{M}$ at P1 (SAZ-west), P2 (PFZ) and P3 (SAZ-east), respectively ( $\mathrm{P} 1\left(\sim 45.82^{\circ} \mathrm{S}, 141.69^{\circ} \mathrm{E}\right)$, $\mathrm{P} 2\left(\sim 54.22^{\circ} \mathrm{S}, 146.54^{\circ} \mathrm{E}\right), \mathrm{P} 3\left(\sim 45.53^{\circ} \mathrm{S}, 153.51^{\circ} \mathrm{E}\right)$; see Fig. 1). Macronutrient concentrations below the mixed layer were higher than surface waters, however in the Subtropical Zone (STZ) and SAZ zones, non-limiting silicate concentrations occurred at depths $>150 \mathrm{~m}$ which was well below the euphotic depth. These zones were generally dominated by non-siliceous phytoplankton groups, although at P1 (SAZwest) a lightly silicified Thalassiosira sp. made up a significant proportion of the biomass, in addition to a high proportion of nanoflagellates (de Salas et al., 2011). P3 (SAZ-east) was characterized by a large abundance of cyanobacteria as well as heterotrophic dinoflagellates (de Salas et al., 2011), 


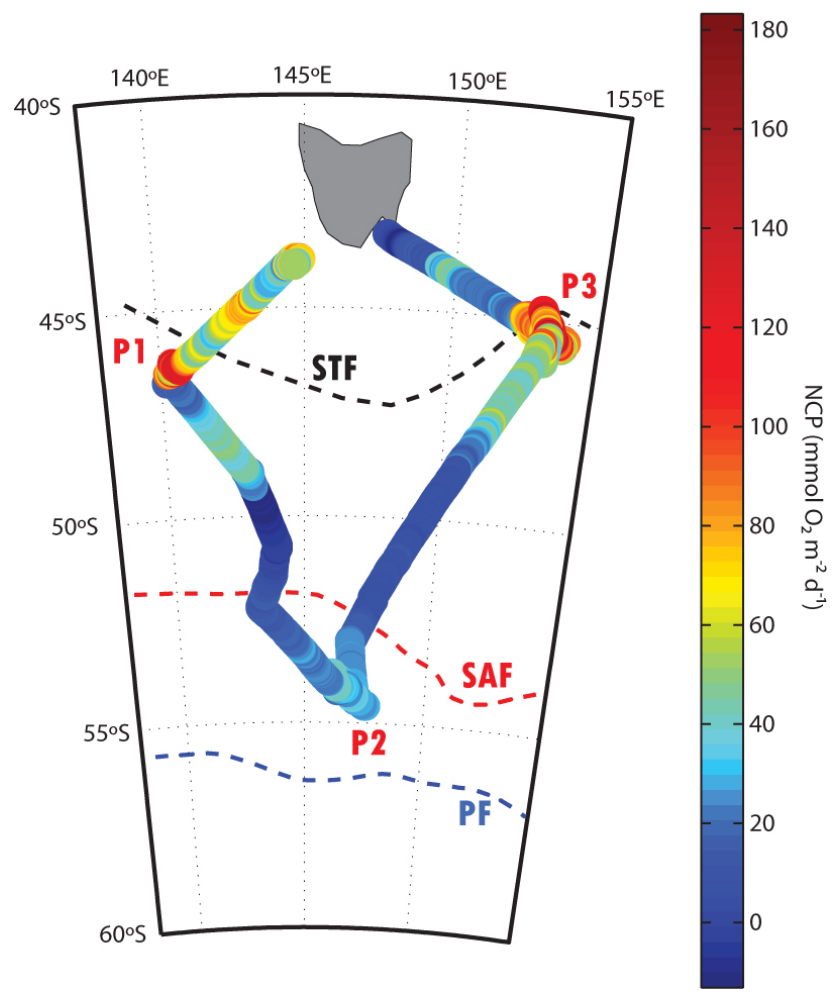

Fig. 1. NCP measurements by EIMS during the SAZ-Sense cruise $\left(\mathrm{mmolO} \mathrm{O}^{-2} \mathrm{~d}^{-1}\right)$. Black, red and blue dashed lines represent the climatological position of the Subtropical (STF), Subantarctic (SAF), and Polar front (PF), based on Orsi et al. (1995). The three process stations are indicated.

and there was significant grazing by microzooplankton in this region (Pearce et al., 2011).

In the PFZ, non-limiting silicate concentrations occurred just below the euphotic depth (65 to $85 \mathrm{~m}$ ), with a deep chlorophyll maximum (DCM) occurring just above the euphotic depth but below the mixed layer (Westwood et al., 2011). Unpublished data (B. Griffiths and B. Tilbrook, 2010) showed that silicate in surface waters was $>10 \mu \mathrm{M}$ during spring, but had been drawn down to limiting concentrations by the time of sampling in summer. Accordingly, the DCM consisted mainly of heavily silicified diatoms as well as nanoflagellates (de Salas et al., 2011), with the population being limited by light availability (Westwood et al., 2011). The mixed layer within the PFZ had a higher relative proportion of autotrophic dinoflagellates and nanoflagellates than the DCM as determined through multidimensional scaling and cluster analysis (de Salas et al., 2011). There was no significant grazing by microzooplankton in the PFZ region (Pearce et al., 2011).

\subsection{Description of $\mathrm{O}_{2}$ saturation, biological $\mathrm{O}_{2}$ saturation, and NCP}

Most of the high frequency variability in total oxygen supersaturation, measured with an optode, can be attributed to biological activity. Physical processes embedded a low frequency but significant signal to the total oxygen supersaturation, as revealed by the difference between total and biological oxygen supersaturation (Fig. 2). These results imply that physical processes influencing oxygen supersaturation (e.g. mixed layer warming, mixing of water masses, atmospheric pressure variations, bubble injection) reflected dispersed atmospheric and oceanic properties whereas biological processes responded to smaller scale oceanographic variability in this region.

Most of the Australian sector SAZ was net autotrophic, except for a small portion of the ship's transect (Fig. 1) that was sampled after a significant storm and which may have been influenced by vertical mixing of oxygen undersaturated waters to the surface. Based on a $0.5^{\circ}$ latitude binning of our 2-min averaged NCP observations within the SAZ (Fig. 1), we estimate NCP during the austral summer 2007 in the Australian sector of the SAZ to be approximately $43 \mathrm{mmol} \mathrm{O}_{2} \mathrm{~m}^{-2} \mathrm{~d}^{-1}$, or $31 \mathrm{mmol} \mathrm{C} \mathrm{m}^{-2} \mathrm{~d}^{-1}$ assuming a molar photosynthetic quotient for new production of $1.4 \mathrm{O}_{2} / \mathrm{CO}_{2}$ as estimated by Laws (1991). This is in line with a value of $52 \mathrm{mmol} \mathrm{O}_{2} \mathrm{~m}^{-2} \mathrm{~d}^{-1}$ determined using a similar method on discrete samples in the same region (Reuer et al., 2007). Large fluctuations in NCP were observed, meridionally, zonally, and within process stations (Figs. 1 and 2). Some of the variability in NCP within process stations was most likely associated with passing water masses, as illustrated by coincident changes in salinity and temperature. However, some of the NCP variation within stations (Fig. 2) was not associated with changes in physical properties of the water.

Subtropical waters south-west of Tasmania had higher NCP than waters south-east of Tasmania. Conversely, Subantarctic waters south-east of Tasmania had higher NCP than south-west of Tasmania, although the differences are smaller. We observed the highest NCP near the Subtropical front, and a general trend of southward decrease in NCP, as reported in previous studies (Reuer et al., 2007; Cassar et al., 2007).

\subsection{Comparison of NCP to other productivity measurements}

$\mathrm{O}_{2} / \mathrm{Ar}$ NCP observations are generally within a factor of two of the oxygen incubation derived NCP (Fig. 3a). In most cases, our estimates exceed those from oxygen incubations, suggesting that the possible negative bias due to vertical mixing of $\mathrm{O}_{2}$ undersaturated deep waters is probably negligible in this region. As expected, NCP correlates with ${ }^{14} \mathrm{C}$ based gross primary productivity measurements (Nielsen, 1951) (Fig. 4b). NCP is equal to GPP minus community respiration 


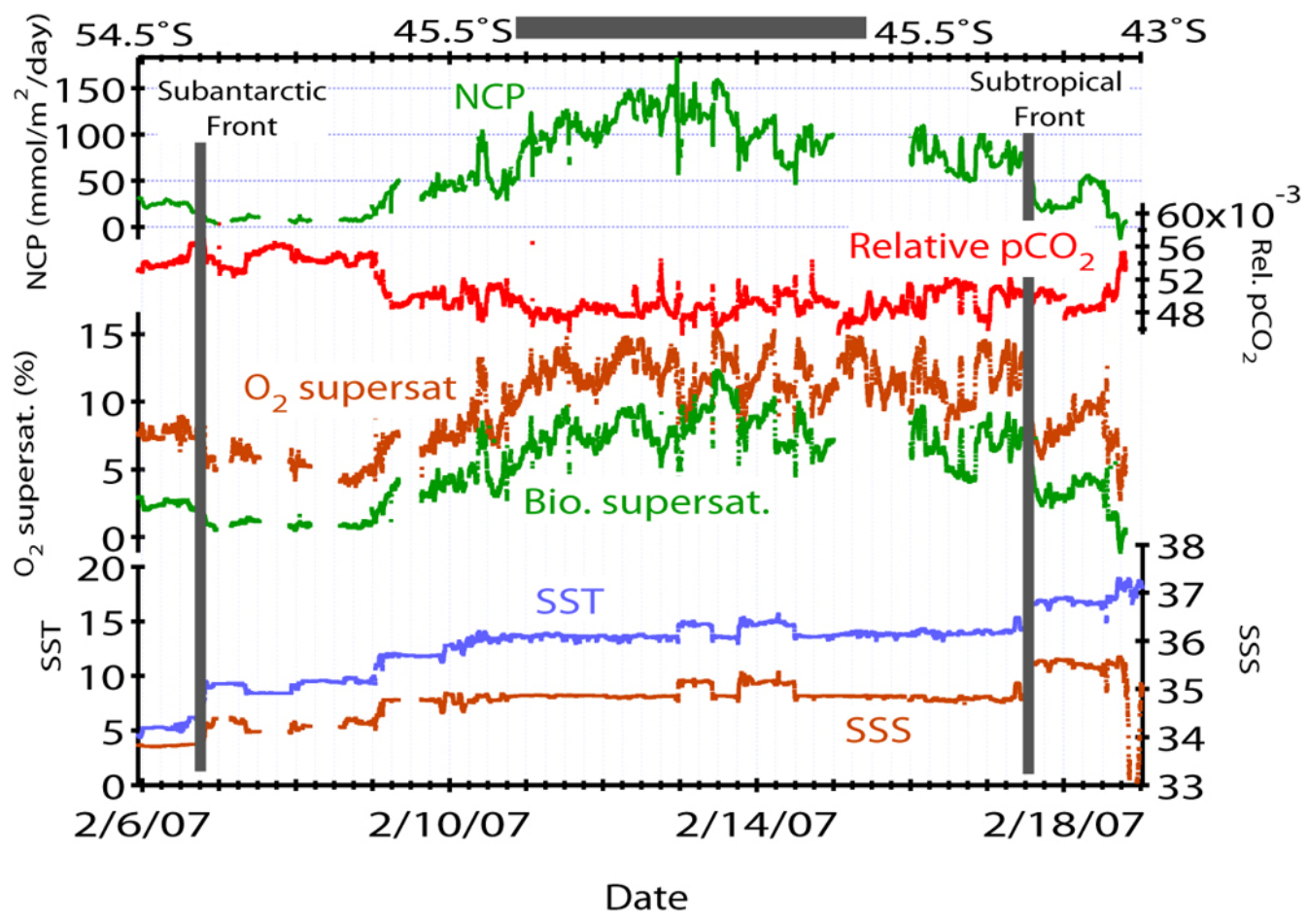

Fig. 2. SAZ-Sense North-bound transect NCP (from in situ $\mathrm{O}_{2} / \mathrm{Ar}$ ), uncalibrated $p \mathrm{CO}_{2}$ (from EIMS mass 44 measurements), total (optode) and biological (EIMS) oxygen supersaturation, and sea surface temperature (SST) and salinity (SSS). Approximate position of fronts is also represented.

(CR) integrated over the mixed layer: NCP should therefore be proportional to GPP if CR is small relative to GPP, if CR varies in a constant proportion, or if GPP is constant. NCP generally scales to chlorophyll biomass integrated over the mixed layer (Fig. 4a), which would be expected since GPP is a function of gross growth rate, the autotrophic $\mathrm{Chl} / \mathrm{C}$ quotient and carbon biomass.

\section{Discussion: controls on NCP}

While it is now clear that Fe regulates algal growth rates in many regions of the Southern Ocean (de Baar et al., 2005; Martin, 1990), its role in carbon export remains ambiguous and mostly based on artificial iron fertilization experiments (Boyd et al., 2004; Buesseler, 2004) and studies of naturallyiron fertilized systems (Blain et al., 2007; Pollard et al., 2009). In order to assess the influence of Fe on mixed-layer $\mathrm{NCP}$, we compare our $\mathrm{O}_{2} / \mathrm{Ar} \mathrm{NCP}$ measurements to that of dissolved Fe concentrations, atmospheric Fe deposition and particulate export fluxes of Fe, and Fe biological sufficiency.

Dissolved $\mathrm{Fe}$ concentrations generally decreased from north to south during the SAZ-Sense cruise (Bowie et al., 2009) (Fig. 3c). Our measured NCP values similarly decrease to the south (Figs. 1 and $3 \mathrm{~d}$ ). The concentration gradient is most likely due to a large supply of Fe further north, from both advection of iron-rich subtropical waters and ae- olian deposition off the Australian continent (Bowie et al., 2009). Although the iron may be entrained or deposited north of the Subtropical front, $\mathrm{N}$ and $\mathrm{P}$ limitation may prevent iron consumption until the water is advected to the SAZ where macronutrient availability increases. Mixing of macronutrient poor/micronutrient rich subtropical waters with macronutrient rich/micronutrient poor subantarctic waters probably enhances primary production at the front. Based on our observations, it is difficult to evaluate whether this is the mechanism leading to intensification of NCP near the STF (see also Bowie et al., 2009). Iron concentrations below the mixed layer in the SAZ are lower than in surface waters, indicating a source of iron delivered either laterally (e.g., originating from shelf sediments) or from above (e.g., originating from atmospheric dusts) (Bowie et al., 2009; Mongin et al., 2011). In the PFZ, the iron concentration profile is reversed, increasing with depth, consistent with major nutrient vertical structure and indicating a predominance of an iron source from below (e.g., via upwelling). It was recently hypothesized that, in addition to advection of iron-rich subtropical waters and atmospheric Fe deposition, higher rates of carbon export to the south might also help to explain the southward decrease in dissolved Fe concentration at the surface (Sedwick et al., 2008). This mechanism is unlikely to be important in the region at the time of the SAZ Sense study as it requires that the meridional gradient in NCP be opposite to our observations (Figs. 1 and 3d). 

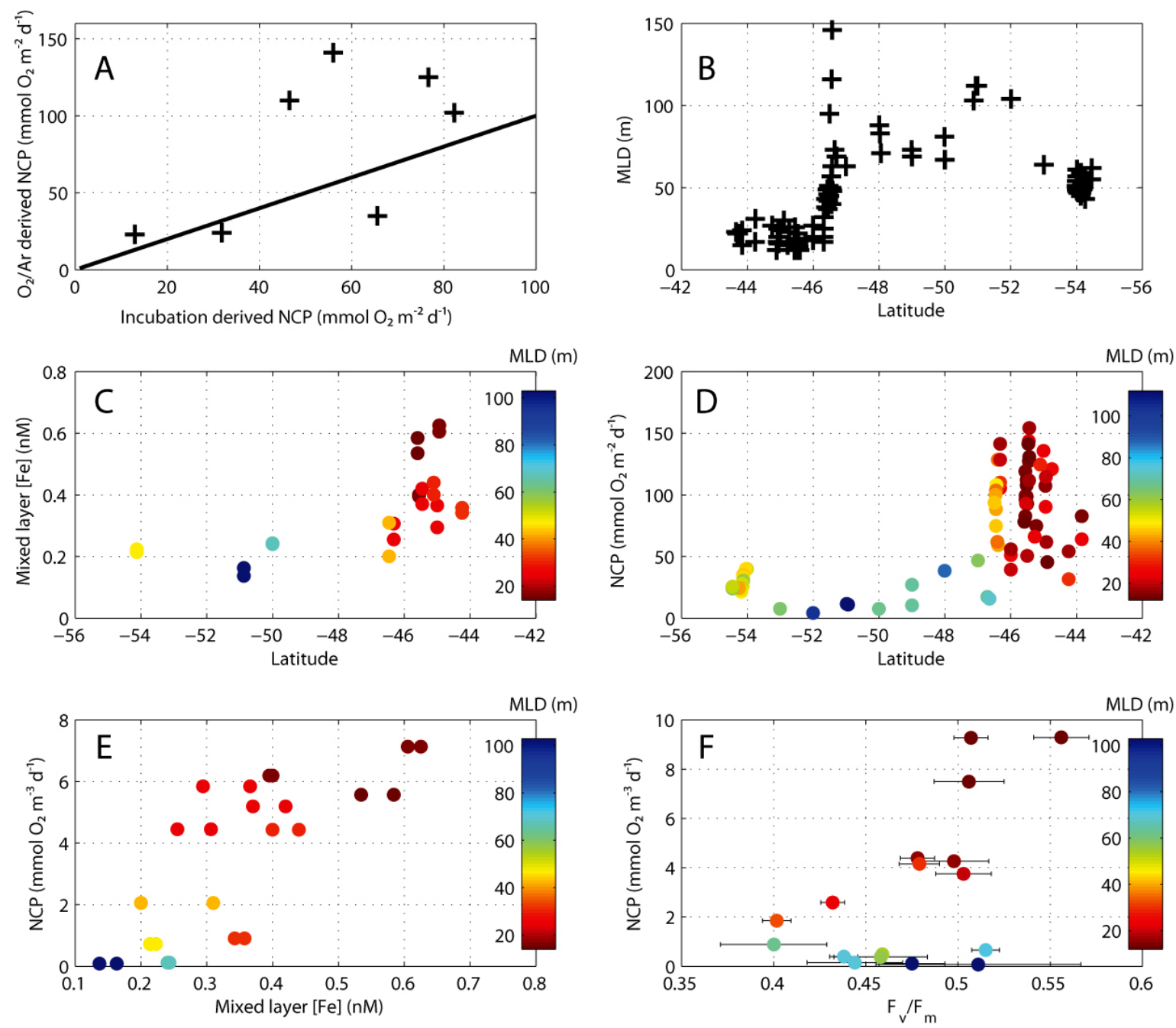

Fig. 3. (A) Mixed-layer $\mathrm{O}_{2} / \mathrm{Ar}$ derived Net Community Productivity (NCP) vs. oxygen incubation derived NCP estimates. Identity slope is also represented (1:1). (B) Mixed layer depth as a function of latitude for the SAZ Sense cruise. Latitudinal variations in average mixed layer $\mathrm{dFe}$ concentration $(\mathrm{nM})(\mathbf{C})$ and NCP integrated over the mixed layer (D). Volumetric NCP as a function of average mixed-layer dFe concentration $(\mathrm{nM})(\mathbf{E})$ and variable fluorescence $(\mathbf{F})$. Points in $(\mathbf{C}-\mathbf{F})$ are color-coded for mixed layer depth (m). MLD is defined as the first depth where the seawater density is $0.05 \mathrm{~kg} \mathrm{~m}^{-3}$ greater than at $10 \mathrm{~m}$ (Rintoul and Trull, 2001). Error bars in (F) represent the standard error of triplicate $F_{\mathrm{V}} / F_{\mathrm{m}}$ measurements.

\subsection{NCP vs. dissolved Fe concentrations}

Dissolved Fe concentrations were within the range of reported half saturation constants for diatoms (Fig. 3c), recognizing the latter's dependence on irradiance (Timmermans et al., 2001b). A statistically significant correlation between volumetric NCP and dissolved Fe concentration was observed $\left(r=0.78, n=24, p=7 \times 10^{-6}\right)$ (Fig. 3e). However, we note that dissolved Fe concentrations in the surface ocean may not equate to $\mathrm{Fe}$ availability since the concentration of a limiting nutrient is also controlled by the efficiency of biological drawdown (i.e. uptake kinetics) as well as by inputs. Given that Fe limits phytoplankton growth in the SAZ, the supply of bioavailable Fe should be rapidly assimilated by autotrophs. For example, although similar Fe concentrations are observed in the mixed layer on and off the Kerguelen plateau, biomass is higher on the plateau due to the higher supply of Fe from vertical mixing (Blain et al., 2007). Conversely, an episodic supply of a limited nutrient, such as the supply of Fe from atmospheric dust deposition, may lead to a correlation between dissolved Fe concentration and fertility. Furthermore, although there was a strong correlation between NCP and dissolved Fe, it is difficult to distinguish the role of $\mathrm{Fe}$ because $\mathrm{Fe}$ was also correlated with mixed layer depth (MLD). 

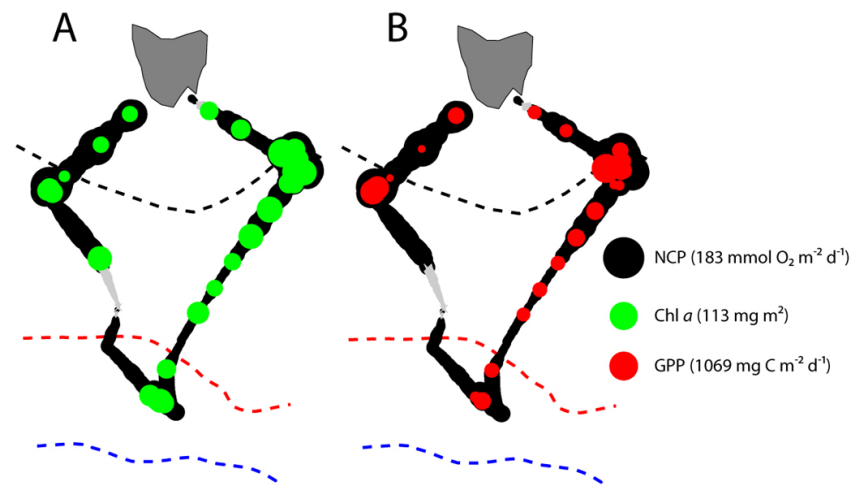

Fig. 4. Mixed-Layer NCP vs. (A) Chl- $a$ (green) (B) depth integrated ${ }^{14} \mathrm{C}$ primary production (red). The diameter of the filled red and green circles indicates the magnitude of the ${ }^{14} \mathrm{C}$ production and Chl- $a$ values. Legend shows the largest corresponding values. Positive and negative NCPs are represented by black and grey symbols, respectively, such that the thickness of the band in each figure is proportional to the continuous NCP measurement. Negative NCP values could result from vertical mixing of $\mathrm{O}_{2}$ undersaturated waters. The black, red, and blue dashed lines represent the climatological positions (Orsi et al., 1995) of the Subtropical, Subantarctic, and Polar fronts, respectively.

\subsection{NCP vs. iron fluxes}

\subsubsection{Particulate Fe at $150 \mathrm{~m}$ depth vs. mixed layer NCP}

Export of particulate $\mathrm{Fe}$ from the surface ocean is a function of both NCP and scavenging. The total downward particulate $\mathrm{Fe}$ export fluxes at $150 \mathrm{~m}$ at process stations $\mathrm{P} 1$ $\left(\sim 45.82^{\circ} \mathrm{S}, 141.69^{\circ} \mathrm{E}\right), \mathrm{P} 2\left(\sim 54.22^{\circ} \mathrm{S}, 146.54^{\circ} \mathrm{E}\right)$, and $\mathrm{P} 3$ $\left(\sim 45.53^{\circ} \mathrm{S}, 153.51^{\circ} \mathrm{E}\right)$ were $166( \pm 89), 69( \pm 14)$, and 213 $( \pm 51) \mathrm{nmol} \mathrm{m}^{-2} \mathrm{~d}^{-1}$, respectively (Bowie et al., 2009). Ratios of particulate Fe export at $150 \mathrm{~m}$ to mixed layer NCP were remarkably similar at the process stations: $1.3,1.7$, and $1.6 \mu \mathrm{mol} \mathrm{mol}^{-1}$ at P1, P2, and P3, respectively. This is a surprising result considering the known differences in community structure, iron fluxes (including scavenging), and iron sources in the region (Bowie et al., 2009; Sedwick et al., 2008). Undoubtedly, some sinking POC and particulate $\mathrm{Fe}$ is remineralized between the base of the mixed layer and $150 \mathrm{~m}$ depth, which will also affect this ratio. The ratio of particulate Fe export to NCP at the base of the mixed layer is expected to be greater than $1.3 \mu \mathrm{mol} \mathrm{mol}^{-1}$ because of attenuation of the particulate $\mathrm{Fe}$ flux between the mixed layer and $150 \mathrm{~m}$. For reference, $\mathrm{Fe}: \mathrm{C}$ in laboratory cultures varies greatly, but is generally greater than $2.5 \mu \mathrm{mol} \mathrm{mol}^{-1}$ (Sunda and Huntsman, 1995).

\subsubsection{NCP vs. aeolian Fe deposition estimates}

There are several candidate sources of iron in the Australian SAZ. These include Ekman transport of upper circumpolar water that has been upwelled south of the Polar Front, lat- eral and vertical mixing of Fe derived from Australia's continental shelves, and atmospheric deposition (Meskhidze et al., 2007; Cassar et al., 2007; Bowie et al., 2009; Gabric et al., 2002; Sedwick et al., 1999). Here, we compare soluble iron deposition fluxes to NCP measurements. In order to assess the importance of aeolian iron supply, soluble $\mathrm{Fe}$ deposition fluxes were sampled and measured according to a method previously described (Wagener et al., 2008) over 8 sections of the cruise track (Supplement Fig. 1). We average our NCP measurements over the same legs. We also assume a Fe/C biological requirement of $2.5 \mu \mathrm{mol} \mathrm{mol}{ }^{-1} \mathrm{C}$ (Maldonado and Price, 1996; Sunda, 1997; Sunda and Huntsman, 1995; Schmidt and Hutchins, 1999; Hassler and Schoemann, 2009; Twining et al., 2004); the exact value does not affect the conclusions that follow. Based on these measurements, during most of the SAZ-Sense cruise, atmospheric soluble iron deposition could support only a small proportion (less than 4\%) of the NCP; the exception is the northeastern transect (between Tasmania and P3), where it could support as much as $40 \%$. Although the total flux of Fe was of the same order of magnitude for all the legs, the $\%$ Fe solubility during the northeastern leg was almost $18 \%$, compared to an average of about $1 \%$ for all other legs. There is evidence based on the OMI Aerosol Index and MODIS observations that forest fires in Tasmania (Australia) may have led to a greater proportion of soluble $\mathrm{Fe}$ in aerosols sampled on the northeastern leg (Bowie et al., 2009; Guieu et al., 2005). It is possible that soluble iron deposition fluxes measured on the ship did not reflect $\mathrm{Fe}$ fluxes that fueled the observed NCP, and also that the fraction of bioavailable $\mathrm{Fe}$ was greater than that determined through the instantaneous leaching approach (Baker and Croot, 2010; Sedwick et al., 2005; Buck et al., 2006). A greater proportion of bioavailable iron, as parameterized in many atmospheric deposition models (e.g. 5-10\%), would obviously enhance the role of atmospheric $\mathrm{Fe}$ in stimulating NCP.

\subsubsection{NCP vs. iron nutritional status}

Given that dissolved Fe concentrations may not be a good indicator of $\mathrm{Fe}$ availability (see above), we turn to variable fluorescence measurements as an index of potential physiological stress associated with Fe limitation of NCP. Light absorbed by phytoplankton has three potential energetic byproducts: $\mathrm{NADP}^{+}$reduction and carbon fixation, heat dissipation, and fluorescence. The ratio of variable fluorescence to maximum fluorescence $\left(F_{\mathrm{v}} / F_{\mathrm{m}}\right)$, reflects the dynamics of photosystem II (PSII) and is indirectly a function of the efficiency with which light energy is used to fix carbon. $F_{\mathrm{v}} / F_{\mathrm{m}}$ is a good indicator of the overall physiological stress of phototrophs, with low values generally indicating excessive light or limitation by nutrients (including $\mathrm{Fe}$ ) (Kolber et al., 1994, 1998; Kolber and Falkowski, 1993; Geider et al., 1993). In the Southern Ocean, where $\mathrm{N}$ and $\mathrm{P}$ are replete and irradiance is moderate, $F_{\mathrm{v}} / F_{\mathrm{m}}$ is generally linked to iron 
limitation stress (Hopkinson et al., 2007). In some regions, $F_{\mathrm{v}} / F_{\mathrm{m}}$ is confounded by taxonomic differences in biophysical properties (Moore et al., 2005; Suggett et al., 2004, 2009), but iron limitation tends to overwhelm the taxonomic signal in HNLC regions such as the Southern Ocean (Suggett et al., 2009).

We find a statistically significant correlation of volumetric NCP with $F_{\mathrm{v}} / F_{\mathrm{m}}$ when the MLD is less than $50 \mathrm{~m}(r=0.78$, $n=8, p=0.02$ ), which is consistent with iron limitation of net community productivity (Fig. 3f). For stations with MLDs greater than $50 \mathrm{~m}$, NCP remains low over large variations in $F_{\mathrm{v}} / F_{\mathrm{m}}$ presumably due to light limitation (discussed below). Interestingly, NCP is negatively correlated with $F_{\mathrm{v}} / F_{\mathrm{m}}$ for MLDs greater than $50 \mathrm{~m}$. This relationship may reflect greater iron availability, and lower NCP, with increased MLDs. Although a pattern is present, the relationship is based on fewer data points than optimal and therefore must be treated with caution.

\subsection{NCP vs. light}

Light is an important regulator of primary productivity in the SAZ (Boyd et al., 1999, 2001) and in the Southern Ocean in general (Mitchell et al., 1991; Nelson and Smith, 1991; Timmermans et al., 2001a; van Oijen et al., 2004). It modulates the response to iron fertilization experiments (de Baar et al., 2005), partly because iron demand increases under low light availability (i.e. iron-light co-limitation) (Strzepek and Price, 2000; Raven, 1990). NCP should increase with light availability in a light-limited system if the increase in gross photosynthesis (i.e. photosynthetic oxygen evolution) is not compensated for by a similar increase in community respiration. Light availability in the mixed layer is a function of photosynthetically active radiation (PAR) at the surface, the light attenuation coefficient, and MLD, which is generally deep in the SAZ (Rintoul and Trull, 2001).

We found that NCP was highest in regions with shallowest mixed-layer depths (Fig. 3d), suggesting a dependence of NCP on light availability in the SAZ (Fig. 3d). Large variations in NCP were observed for stations with shallow MLDs, possibly reflecting gradients in Fe and light availability, recent physical disturbance, and the fact that MLD was not the only factor affecting light availability. NCP was always low for MLD greater than $50 \mathrm{~m}$, consistent with the dominance of light limitation in these waters.

\section{Conclusions}

We have reported evidence that NCP production in the SAZ and PFZ is subject to limitation by light and iron. NCP was correlated to dissolved $\mathrm{Fe}$ concentrations and, for shallower mixed layers $(<50 \mathrm{~m})$, to phytoplankton variable fluorescence, which has been shown to reflect physiological iron limitation stress in the Southern Ocean. Our results suggest a dependence of NCP on iron in the open ocean regions of the Southern Ocean, similar to the one observed under the "mass island effect" (Blain et al., 2007; Pollard et al., 2009). Our results should however be interpreted with caution. First, the strong correlation between NCP and dissolved Fe may be difficult to interpret because of the correlation of dissolved $\mathrm{Fe}$ to MLD and because the concentration of a limiting nutrient can be a poor predictor of its availability. The correlation of NCP to $F_{\mathrm{v}} / F_{\mathrm{m}}$ is a more reliable predictor of the influence of iron limitation on carbon fluxes out of the mixed layer. The latter relationship will benefit from more extensive studies. At stations with deeper mixed layers, NCP was low, regardless of the phytoplankton's iron sufficiency, consistent with light limitation of NCP, most likely through a direct influence on primary production. Climate change models predict shifts in atmospheric and oceanic circulation dynamics (Fyfe and Saenko, 2006; Thompson, 2002; Cai and Cowan, 2007). Such changes will impact light and iron supply and availability in the Southern Ocean and potentially the strength of the biological pump. Further studies of carbon export production from the surface ocean and of the fate of the exported carbon are essential if the role of this region in future carbon budgets is to be adequately predicted.

\section{Supplementary material related to this article is available online at: http://www.biogeosciences.net/8/227/2011/ bg-8-227-2011-supplement.pdf.}

Acknowledgements. We would like to thank Thibaut Wagener (IFM-GEOMAR) for providing the atmospheric $\mathrm{Fe}$ deposition data, Richard Matear and Thomas Trull (CSIRO, Australia) for helpful discussions, Brian Griffiths for acting as Chief Scientist on SAZ-Sense, and the officers and crew of the R/V Aurora Australis for technical support. This work was partly supported by the Australian Government's Cooperative Research Centres Programme through the Antarctic Climate and Ecosystems Cooperative Research Centre (ACE CRC) and Australian Antarctic Science project \#2720, by grants from the National Science Foundation Office of Polar Programs and NASA, and by the Princeton-BP/Amoco Carbon Mitigation Initiative.

Edited by: K. Suzuki

\section{References}

Baker, A. R. and Croot, P. L.: Atmospheric and marine controls on aerosol iron solubility in seawater, Mar. Chem., 120, 4-13, 2010.

Blain, S., Queguiner, B., Armand, L., Belviso, S., Bombled, B. Bopp, L., Bowie, A., Brunet, C., Brussaard, C., Carlotti, F., Christaki, U., Corbiere, A., Durand, I., Ebersbach, F., Fuda, J. L., Garcia, N., Gerringa, L., Griffiths, B., Guigue, C., Guillerm, C., Jacquet, S., Jeandel, C., Laan, P., Lefevre, D., Lo Monaco, C., Malits, A., Mosseri, J., Obernosterer, I., Park, Y. H., Picheral, M., Pondaven, P., Remenyi, T., Sandroni, V., Sarthou, G., Savoye, N., Scouarnec, L., Souhaut, M., Thuiller, D., Timmermans, K., Trull, 
T., Uitz, J., van Beek, P., Veldhuis, M., Vincent, D., Viollier, E., Vong, L., and Wagener, T.: Effect of natural iron fertilization on carbon sequestration in the Southern Ocean, Nature, 446, 10701075, doi:10.1038/nature05700, 2007.

Bowie, A. R. and Lohan, M. C.: Analysis of Iron in Seawater, in: Practical Guidelines for the Analysis of Seawater, edited by: Wurl, O., Taylor and Francis, Boca Raton, FL, USA, 235-257, 2009.

Bowie, A. R., Lannuzel, D., Remenyi, T. A., Wagener, T., Lam, P. J., Boyd, P. W., Guieu, C., Townsend, A. T., and Trull, T. W.: Biogeochemical iron budgets of the Southern Ocean south of Australia: summertime supply decouples iron and nutrient cycles in the subantarctic zone, Global Biogeochem. Cy., 23, GB4034, doi:10.1029/2009GB003500, 2009.

Bowie, A. R., Griffiths, F. B., Dehairs, F., and Trull, T. W.: Oceanography of the subantarctic and polar frontal zones south of Australia during summer: setting for the SAZ-Sense study, Deep-Sea Res. Pt. II, in review, 2011.

Boyd, P., LaRoche, J., Gall, M., Frew, R., and McKay, R. M. L.: Role of iron, light, and silicate in controlling algal biomass in subantarctic waters SE of New Zealand, J. Geophys. Res.Oceans, 104, 13395-13408, 1999.

Boyd, P. W., Crossley, A. C., DiTullio, G. R., Griffiths, F. B., Hutchins, D. A., Queguiner, B., Sedwick, P. N., and Trull, T. W.: Control of phytoplankton growth by iron supply and irradiance in the subantarctic Southern Ocean: Experimental results from the SAZ Project, J. Geophys. Res.-Oceans, 106, 31573-31583, 2001.

Boyd, P. W., Law, C. S., Wong, C. S., Nojiri, Y., Tsuda, A., Levasseur, M., Takeda, S., Rivkin, R., Harrison, P. J., Strzepek, R., Gower, J., McKay, R. M., Abraham, E., Arychuk, M., BarwellClarke, J., Crawford, W., Crawford, D., Hale, M., Harada, K., Johnson, K., Kiyosawa, H., Kudo, I., Marchetti, A., Miller, W., Needoba, J., Nishioka, J., Ogawa, H., Page, J., Robert, M., Saito, H., Sastri, A., Sherry, N., Soutar, T., Sutherland, N., Taira, Y., Whitney, F., Wong, S. K. E., and Yoshimura, T.: The decline and fate of an iron-induced subarctic phytoplankton bloom, Nature, 428, 549-553, 2004.

Buck, C. S., Landing, W. M., Resing, J. A., and Lebon, G. T.: Aerosol iron and aluminum solubility in the northwest Pacific Ocean: Results from the 2002 IOC cruise, Geochem. Geophy. Geosy., 7, Q04M07, doi:10.1029/2005GC000977, 2006.

Buesseler, K. O., Andrews, J. E., Pike, S. M., and Charette, M. A.: The effects of iron fertilization on carbon sequestration in the Southern Ocean, Science, 304, 414-417, 2004.

Cai, W. J. and Cowan, T.: Trends in Southern Hemisphere circulation in IPCC AR4 models over 1950-99: Ozone depletion versus greenhouse forcing, J. Climate, 20, 681-693, 2007.

Cassar, N., Bender, M. L., Barnett, B. A., Fan, S., Moxim, W. J., Levy, H., and Tilbrook, B.: The Southern Ocean biological response to aeolian iron deposition, Science, 317, 1067-1070, 2007.

Cassar, N., Barnett, B. A., Bender, M. L., Kaiser, J., Hamme, R. C., and Tilbrook, B.: Continuous High-Frequency Dissolved $\mathrm{O}_{2} / \mathrm{Ar}$ Measurements by Equilibrator Inlet Mass Spectrometry, Anal. Chem., 81, 1855-1864, 2009.

Craig, H. and Hayward, T.: Oxygen supersaturation in the ocean biological versus physical contributions, Science, 235, 199-202, 1987. de Baar, H. J. W., Boyd, P. W., Coale, K. H., Landry, M. R., Tsuda, A., Assmy, P., Bakker, D. C. E., Bozec, Y., Barber, R. T., Brzezinski, M. A., Buesseler, K. O., Boye, M., Croot, P. L., Gervais, F., Gorbunov, M. Y., Harrison, P. J., Hiscock, W. T., Laan, P., Lancelot, C., Law, C. S., Levasseur, M., Marchetti, A., Millero, F. J., Nishioka, J., Nojiri, Y., van Oijen, T., Riebesell, U., Rijkenberg, M. J. A., Saito, H., Takeda, S., Timmermans, K. R., Veldhuis, M. J. W., Waite, A. M., and Wong, C. S.: Synthesis of iron fertilization experiments: From the iron age in the age of enlightenment, J. Geophys. Res.-Oceans, 110, C09S16, doi:10.1029/2004JC002601, 2005.

de Salas, M. F., Eriksen, R., Davidson, A. T., and Wright, S. W.: Protistan communities in the Australian sector of the subantarctic zone during SAZ-Sense, Deep-Sea Res. Pt. II, in press, 2011.

Emerson, S.: Seasonal oxygen cycles and biological new production in surface waters of the sub-Arctic Pacific Ocean, J. Geophys. Res.-Oceans, 92, 6535-6544, 1987.

Emerson, S., Quay, P., and Wheeler, P. A.: Biological productivity determined from oxygen mass-balance and incubation experiments, Deep-Sea Res. Pt. I, 40, 2351-2358, 1993.

Falkowski, P. G., Laws, E. A., Barber, R. T., and Murray, J. W.: Phytoplankton, and their role in primary, new and export production, in: Ocean Biogeochemistry, edited by: Fasham, M. J. R., Springer, New York, 109-111, 2003.

Franck, V. M., Brzezinski, M. A., Coale, K. H., and Nelson, D. M.: Iron and silicic acid concentrations regulate Si uptake north and south of the polar frontal zone in the Pacific sector of the Southern Ocean, Deep-Sea Res. Pt. II, 47, 3315-3338, 2000.

Fyfe, J. C. and Saenko, O. A.: Simulated changes in the extratropical southern hemisphere winds and currents, Geophys. Res. Lett., 33, L06701, doi:06710.01029/02005GL025332., 2006.

Gaarder, T. and Gran, H. H.: Investigations of the production of plankton in the Oslo fjord, Rapp. Proc. Verb. Cons. Int. Explor. Mer. 42, 3-48, 1927.

Gabric, A. J., Cropp, R., Ayers, G. P., McTainsh, G., and Braddock, R.: Coupling between cycles of phytoplankton biomass and aerosol optical depth as derived from SeaWiFS time series in the Subantarctic Southern Ocean, Geophys. Res. Lett., 29, 1112, doi:1110.1029/2001GL013545, 2002.

Garcia, H. E. and Gordon, L. I.: Oxygen solubility in seawater - better fitting equations, Limnol. Oceanogr., 37, 1307-1312, 1992.

Geider, R. J., Laroche, J., Greene, R. M., and Olaizola, M.: Response of the photosynthetic apparatus of Phaeodactylum tricornutum (Bacillariophyceae) to nitrate, phosphate, or iron starvation, J. Phycol., 29, 755-766, 1993.

Guieu, C., Bonnet, S., Wagener, T., and Loye-Pilot, M. D.: Biomass burning as a source of dissolved iron to the open ocean?, Geophys. Res. Lett., 32, L19608, doi:19610.11029/12005GL022962, 2005.

Hassler, C. S. and Schoemann, V.: Bioavailability of organically bound Fe to model phytoplankton of the Southern Ocean, Biogeosciences, 6, 2281-2296, doi:10.5194/bg-6-2281-2009, 2009.

Herraiz-Borreguero, L. and Rintoul, S. R.: Regional circulation and its impact on upper ocean variability south of Tasmania (Australia), Deep-Sea Res. Pt. II, in press, 2011.

Hopkinson, B. M., Mitchell, G., Reynolds, R. A., Wang, H., Selph, K. E., Measures, C. I., Hewes, C. D., Holm-Hansen, O., and Barbeau, K. A.: Iron limitation across chlorophyll gradients in the southern Drake Passage: Phytoplankton responses to iron 
addition and photosynthetic indicators of iron stress, Limnol. Oceanogr., 52, 2540-2554, 2007.

Johnson, K. M., Dickson, A. G., Eischeid, G., Goyet, C., Guenther, P., Key, R. M., Millero, F. J., Purkerson, D., Sabine, C. L., Schottle, R. G., Wallace, D. W. R., Wilke, R. J., and Winn, C. D.: Coulometric total carbon dioxide analysis for marine studies: assessment of the quality of total inorganic carbon measurements made during the US Indian Ocean $\mathrm{CO}_{2}$ Survey 1994-1996, Mar. Chem., 63, 21-37, 1998.

Kalnay, E., Kanamitsu, M., Kistler, R., Collins, W., Deaven, D., Gandin, L., Iredell, M., Saha, S., White, G., Woollen, J., Zhu, Y., Chelliah, M., Ebisuzaki, W., Higgins, W., Janowiak, J., Mo, K. C., Ropelewski, C., Wang, J., Leetmaa, A., Reynolds, R., Jenne, R., and Joseph, D.: The NCEP/NCAR 40-year reanalysis project, B. Am. Meteorol. Soc., 77, 437-471, 1996.

Kolber, Z. and Falkowski, P. G.: Use of active fluorescence to estimate phytoplankton photosynthesis in situ, Limnol. Oceanogr., 38, 1646-1665, 1993.

Kolber, Z. S. and Falkowski, P. G.: Fast repetition rate (FRR) fluorometer for making in situ measurements of primary productivity, Report BNL-47921; CONF-921066-1, 1992.

Kolber, Z. S., Barber, R. T., Coale, K. H., Fitzwater, S. E., Greene, R. M., Johnson, K. S., Lindley, S., and Falkowski, P. G.: Iron limitation of phytoplankton photosynthesis in the Equatorial Pacific Ocean, Nature, 371, 145-149, 1994.

Kolber, Z. S., Prasil, O., and Falkowski, P. G.: Measurements of variable chlorophyll fluorescence using fast repetition rate techniques: defining methodology and experimental protocols, BBABioenergetics, 1367, 88-106, 1998.

Laws, E. A.: Photosynthetic quotients, new production and net community production in the open ocean, Deep-Sea Res. A, 38, 143-167, 1991.

Lefevre, D., Guigue, C., and Obernosterer, I.: The metabolic balance at two contrasting sites in the Southern Ocean: The iron-fertilized Kerguelen area and HNLC waters, Deep-Sea Res. Pt. II, 55, 766-776, 2008.

Lewis, M. R. and Smith, J. C.: A small volume, short-incubationtime method for measurement of photosynthesis as a function of incident irradiance, Mar. Ecol.-Prog. Ser., 13, 99-102, 1983.

Maldonado, M. T. and Price, N. M.: Influence of N substrate on Fe requirements of marine centric diatoms, Mar. Ecol.-Prog. Ser., 141, 161-172, 1996.

Martin, J. H.: Glacial-interglacial $\mathrm{CO}_{2}$ change: The iron hypothesis, Paleoceanography, 5, 1-13, 1990.

Martinez-Garcia, A., Rosell-Mele, A., Geibert, W., Gersonde, R., Masque, P., Gaspari, V., and Barbante, C.: Links between iron supply, marine productivity, sea surface temperature, and $\mathrm{CO}_{2}$ over the last 1.1. Ma, Paleoceanography, 24, PA1207, doi:10.1029/2008PA001657, 2009.

Meskhidze, N., Nenes, A., Chameides, W. L., Luo, C., and Mahowald, N.: Atlantic Southern Ocean productivity: Fertilization from above or below?, Global Biogeochem. Cy., 21, GB2006, doi:10.1029/2006GB002711, 2007.

Mitchell, B. G., Brody, E. A., Holm-Hansen, O., Mcclain, C., and Bishop, J.: Light limitation of phytoplankton biomass and macronutrient utilization in the Southern-Ocean, Limnol. Oceanogr., 36, 1662-1677, 1991.

Mongin, M., Matear, R., and Chamberlain, M.: Distribution of chlorophyll and iron supplies in the Sub Antarctic Zone South of Australia, Deep-Sea Res. Pt. II, in press, 2011.

Moore, C. M., Lucas, M. I., Sanders, R., and Davidson, R.: Basinscale variability of phytoplankton bio-optical characteristics in relation to bloom state and community structure in the Northeast Atlantic, Deep-Sea Res. Pt. I, 52, 401-419, 2005.

Nelson, D. M. and Smith, W. O.: Sverdrup revisited - critical depths, maximum chlorophyll levels, and the control of Southern-Ocean productivity by the irradiance-mixing regime, Limnol. Oceanogr., 36, 1650-1661, 1991.

Nelson, D. M. and Treguer, P.: Role of silicon as a limiting nutrient to Antarctic diatoms - evidence from kinetic studies in the Ross Sea ice-edge zone, Mar. Ecol.-Prog. Ser., 80, 255-264, 1992.

Nielsen, E. S.: Measurement of the production of organic matter in the sea by means of carbon-14, Nature, 167, 684-685, 1951.

Pearce, I., Davidson, A. T., Thomson, P. G., Wright, S., and van den Enden, R.: Marine microbial ecology in the Sub-Antarctic Zone: rates of bacterial and phytoplankton growth and grazing by heterotrophic protists, Deep-Sea Res. Pt. II, in press, 2011.

Platt, T., Gallegos, C. L., and Harrison, W. G.: Photoinhibition of photosynthesis in natural assemblages of marine phytoplankton, J. Mar. Res., 38, 687-701, 1980.

Pollard, R. T., Salter, I., Sanders, R. J., Lucas, M. I., Moore, C. M., Mills, R. A., Statham, P. J., Allen, J. T., Baker, A. R., Bakker, D. C. E., Charette, M. A., Fielding, S., Fones, G. R., French, M., Hickman, A. E., Holland, R. J., Hughes, J. A., Jickells, T. D., Lampitt, R. S., Morris, P. J., Nedelec, F. H., Nielsdottir, M., Planquette, H., Popova, E. E., Poulton, A. J., Read, J. F., Seeyave, S., Smith, T., Stinchcombe, M., Taylor, S., Thomalla, S., Venables, H. J., Williamson, R., and Zubkov, M. V.: Southern Ocean deep-water carbon export enhanced by natural iron fertilization, Nature, 457, 577-580, doi:10.1038/nature07716, 2009.

Raven, J. A.: Predictions of Mn and Fe use efficiencies of phototrophic growth as a function of light availability for growth, New Phytol., 116, 1-18, 1990.

Reuer, M. K., Barnett, B. A., Bender, M. L., Falkowski, P. G., and Hendricks, M. B.: New estimates of Southern Ocean biological production rates from $\mathrm{O}_{2} / \mathrm{Ar}$ Ratios and the triple isotope composition of $\mathrm{O}_{2}$, Deep-Sea Res. Pt. I, 54, 951-974, 2007.

Rintoul, S. R. and Trull, T. W.: Seasonal evolution of the mixed layer in the Subantarctic Zone south of Australia, J. Geophys. Res.-Oceans, 106, 31447-31462, 2001.

Sarmiento, J. L., Gruber, N., Brzezinski, M. A., and Dunne, J. P.: High-latitude controls of thermocline nutrients and low latitude biological productivity, Nature, 427, 56-60, 2004.

Schmidt, M. A. and Hutchins, D. A.: Size-fractionated biological iron and carbon uptake along a coastal to offshore transect in the NE Pacific, Deep-Sea Res. Pt. II, 46, 2487-2503, 1999.

Schreiber, U.: Pulse-Amplitude-Modulated (PAM) fluorometry and saturation pulse method, in: Chlorophyll a Fluorescence: A Signature of Photosynthesis, edited by: Govindjee, G. C. P. a., Springer, Dordrecht, 279-319, 2004.

Sedwick, P. N., DiTullio, G. R., Hutchins, D. A., Boyd, P. W., Griffiths, F. B., Crossley, A. C., Trull, T. W., and Queguiner, B.: Limitation of algal growth by iron deficiency in the Australian Subantarctic region, Geophys. Res. Lett., 26, 2865-2868, 1999.

Sedwick, P. N., Church, T. M., Bowie, A. R., Marsay, C. M., Ussher, S. J., Achilles, K. M., Lethaby, P. J., Johnson, R. J., Sarin, M. M., and McGillicuddy, D. J.: Iron in the Sargasso Sea (Bermuda Atlantic Time-series Study region) during summer: Eolian imprint, 
spatiotemporal variability, and ecological implications, Global Biogeochem. Cy., 19, GB4006, doi:4010.1029/2004GB002445, 2005.

Sedwick, P. N., Bowie, A. R., and Trull, T. W.: Dissolved iron in the Australian sector of the Southern Ocean (CLIVAR SR3 section): Meridional and seasonal trends, Deep-Sea Res. Pt. I, 55, 911925, 2008.

Sigman, D. M. and Boyle, E. A.: Glacial/interglacial variations in atmospheric carbon dioxide, Nature, 407, 859-869, 2000.

Sokolov, S. and Rintoul, S. R.: Subsurface structure of interannual temperature anomalies in the Australian sector of the Southern Ocean, J. Geophys. Res.-Oceans, 108, 3285, doi:3210.1029/2002JC001494, 2003.

Spitzer, W. S. and Jenkins, W. J.: Rates of vertical mixing, gasexchange and new production - estimates from seasonal gas cycles in the upper ocean near Bermuda, J. Mar. Res., 47, 169-196, 1989.

Strzepek, R. F. and Price, N. M.: Influence of irradiance and temperature on the iron content of the marine diatom Thalassiosira weissflogii (Bacillariophyceae), Mar. Ecol.-Prog. Ser., 206, 107$117,2000$.

Suggett, D. J., MacIntyre, H. L., and Geider, R. J.: Evaluation of biophysical and optical determinations of light absorption by photosystem II in phytoplankton, Limnol. Oceanogr.-Meth., 2, 316-332, 2004.

Suggett, D. J., Moore, C. M., Hickman, A. E., and Geider, R. J.: Interpretation of fast repetition rate (FRR) fluorescence: signatures of phytoplankton community structure versus physiological state, Mar. Ecol.-Prog. Ser., 376, 1-19, 2009.

Sunda, W. G.: Control of dissolved iron concentrations in the world ocean: A comment, Mar. Chem., 57, 169-172, 1997.

Sunda, W. G. and Huntsman, S. A.: Iron uptake and growth limitation in oceanic and coastal phytoplankton, Mar. Chem., 50, 189-206, 1995.

Thompson, D. W. J. and S. Solomon: Interpretation of recent Southern Hemisphere climate change, Science, 296, 895-899, 2002.

Timmermans, K. R., Davey, M. S., van der Wagt, B., Snoek, J., Geider, R. J., Veldhuis, M. J. W., Gerringa, L. J. A., and de Baar, H. J. W.: Co-limitation by iron and light of Chaetoceros brevis, Cdichaeta and C-calcitrans (Bacillariophyceae), Mar. Ecol.-Prog. Ser., 217, 287-297, 2001a.
Timmermans, K. R., Gerringa, L. J. A., de Baar, H. J. W., van der Wagt, B., Veldhuis, M. J. W., de Jong, J. T. M., Croot, P. L., and Boye, M.: Growth rates of large and small Southern Ocean diatoms in relation to availability of iron in natural seawater, Limnol. Oceanogr., 46, 260-266, 2001b.

Trull, T., Rintoul, S. R., Hadfield, M., and Abraham, E. R.: Circulation and seasonal evolution of polar waters south of Australia: Implications for iron fertilization of the Southern Ocean, DeepSea Res. Pt. II, 48, 2439-2466, 2001.

Twining, B. S., Baines, S. B., and Fisher, N. S.: Element stoichiometries of individual plankton cells collected during the Southern Ocean Iron Experiment (SOFeX), Limnol. Oceanogr., 49, 2115-2128, 2004.

van Oijen, T., van Leeuwe, M. A., Granum, E., Weissing, F. J., Bellerby, R. G. J., Gieskes, W. W. C., and de Baar, H. J. W.: Light rather than iron controls photosynthate production and allocation in Southern Ocean phytoplankton populations during austral autumn, J. Plankton Res., 26, 885-900, 2004.

Wagener, T., Guieu, C., Losno, R., Bonnet, S., and Mahowald, N.: Revisiting atmospheric dust export to the Southern Hemisphere ocean: Biogeochemical implications, Global Biogeochem. Cy., 22, GB2006, doi:2010.1029/2007GB002984, 2008.

Wanninkhof, R.: Relationship between wind-speed and gasexchange over the ocean, J. Geophys. Res.-Oceans, 97, 73737382, 1992.

Westwood, K. J., Griffiths, F. B., Webb, J. P., and Wright, S. W.: Primary productivity in the Sub-Antarctic and Polar Frontal zones south of Tasmania, Australia; SAZ-Sense survey, 2007, DeepSea Res. Pt. II, in press, 2011.

Williams, P. J. L. and Jenkinson, N. W.: A transportable microprocessor-controlled precise Winkler titration suitable for field station and shipboard use, Limnol. Oceanogr., 27, 576-584, 1982. 